\title{
EFFECT OF PHOSPHATE FERTILIZATION AND BASE SATURATION OF SUBSTRATE ON THE SEEDLINGS GROWTH AND QUALITY OF Plathymenia foliolosa Benth. ${ }^{1}$
}

\author{
Eliane Cristina Sampaio de Freitas ${ }^{2 *}$, Haroldo Nogueira de Paiva ${ }^{3}$, Helio Garcia Leite ${ }^{3}$ and Sílvio Nolasco \\ de Oliveira $\mathrm{Neto}^{3}$

\footnotetext{
${ }^{1}$ Received on 06.01.2015 accepted for publication on 25.10.2016.

${ }^{2}$ Universidade Federal de Viçosa, Programa de Pós-Graduação em Ciência Florestal, Viçosa, Minas Gerais - Brasil.. E-mail: $<$ eliane.freitas@ufv.br>.

${ }^{3}$ Universidade Federal de Viçosa, Departamento de Engenharia Florestal, Viçosa, MG - Brasil. E-mail: <hnpaiva@ufv.br>, $<$ hgleite@ufv.br> and < snolasco@ufv.br>.

*Corresponding author.
}

\begin{abstract}
This study aimed to evaluate the growth and quality of seedlings of Plathymenia foliolosa Benth in response to base saturation of substrate and phosphate fertilization. The treatments were arranged in a factorial design of $6 \mathrm{P}$ levels $\left(0,120,240,360,480\right.$ and $\left.600 \mathrm{mg} \mathrm{dm}^{-3}\right)$ by 5 base saturation levels $(3.5$, $25,40,55,70 \%)$, in randomized blocks with four replications. The height of aerial part, neck diameter, shoot dry matter, root dry matter and total dry matter were determined at 118 days after the transplanting. It was still calculated the relation shoot dry matter/root dry matter and the Dickson Quality Index. There were significant effects of the phosphate fertilization for all studied variables. The base saturation had influence on all studied variables, except for the shoot dry matter/root dry matter relation. No significant effect of the interaction between base saturation of substrate and phosphate fertilization was observed on seedlings growth and quality. For the studied conditions, it is recommended $300 \mathrm{mg} \mathrm{dm}^{-3}$ of $\mathrm{P}$ for the production of quality seedlings of Plathymenia foliolosa without the necessity of liming.
\end{abstract}

Keywords: Phosphorus; Seedlings Production; Liming.

\section{EFEITO DA ADUBAÇÃO FOSFATADA E SATURAÇÃO POR BASES DO SUBSTRATO SOB O CRESCIMENTO E A QUALIDADE DE MUDAS DE Plathymenia foliolosa Benth.}

\begin{abstract}
RESUMO-O objetivo deste estudo foi avaliar o crescimento e a qualidade de mudas de Plathymenia foliolosa Benth. (vinhático-da-mata) em resposta à adubação fosfatada e saturação por bases do substrato. Os tratamentos foram representados por um fatorial de seis níveis de fósforo $\left(0,120,240,360,480\right.$ e $\left.600 \mathrm{mg} \mathrm{dm}^{-3}\right)$ por cinco níveis de saturação por bases do substrato $(3,5,25,40,55,70 \%)$, sendo dispostos no delineamento em blocos ao acaso, com quatro repetições. Aos 118 dias após a repicagem, foram obtidas a altura da parte aérea (H), o diâmetro do coleto (D), a massa de matéria seca da parte aérea (SDM), de raizes (RDM) e total (TDM), e calculada a relação SDM/RDM e o indice de qualidade de Dickson (DQI). A adubação fosfatada teve efeito significativo para todas as variáveis estudadas. O efeito da saturação por bases também foi significativo, exceto para a SDM/RDM. Não foi observado efeito significativo para a interação entre saturação por bases e adubação fosfatada. Para as condições estudadas, recomenda-se a aplicação de $300 \mathrm{mg} \mathrm{dm}^{-3} \mathrm{de} P$, sem necessidade de calagem, para a produção de mudas de vinhático-da-mata.
\end{abstract}

Palavras-chave: Fósforo; Produção de mudas; Calagem. 


\section{INTRODUCTION}

In Brazil, the recovery projects of degraded areas have become essential to the reestablishment of environmental balance, once the natural regeneration has not often been able to satisfactorily recover the vegetation cover and previously existing species in the area. Given the current scenario, the priority of the recovery projects is to replant with native species the sites that have been degraded by mining, construction, construction of hydroelectric plant reservoirs, or even the use of land for agricultural purposes (Fernandes et al., 2000).

Legumes species stand out in degraded areas recovery because they favor the nutrients cycling (Costa et al., 2004), since its litter is a source of organic matter rich of nutrients, mainly $\mathrm{N}$, resulting in an improved soil fertility and the stimulation of biological activity (Gonçalves et al., 2005).

The Plathymenia foliolosa belongs to the family Fabaceae and subfamily Mimosoideae. The tree is lush and ornamental and can reach a height of $30 \mathrm{~m}$, and its wood is widely used in luxury furniture, construction, manufacture of decorative veneer panels and wine barrels (Lorenzi, 2002). This is an early successional species (Silva et al., 2003), with occurrence from Pernambuco to Rio de Janeiro, but more often in Minas Gerais, Espírito Santo and Rio de Janeiro in the Atlantic Forest, usually occurring on high ground, in more or less dry forests, mainly inside the dense forest (Lorenzi, 2002).

The use of native species of trees for timber or environmental purposes is still difficult in most cases due the lack of information on the nutritional requirements of these species for the production of seedlings, establishment and development of plants in the field (Gonçalves et al., 2010).

Seedlings of good quality are crucial for the success of reforestation projects because they have greater resistance to adverse environmental conditions and less time for their establishment (Cruz et al., 2004). In order to the seedlings in the nursery grow properly both in height, diameter and in mass production it is essential that the substrate contains the necessary nutrients (Ceconi et al., 2006). However, for the production of native species seedlings, recommendations for fertilization of other species of greater economic interest have been used due to lack of knowledge and information about their nutritional requirements.
In the production of seedlings, the deficiency of phosphorus in the substrates causes irregular growth, both in the aerial part and the root system, impairing their quality (Gomes and Paiva, 2012). This nutrient is essential for the growth and development of plants and is part of most metabolic processes, such as photosynthesis, respiration, storage and energy transfer (Dechen and Nachtigall, 2007). Nevertheless, tropical soils usually present low phosphorus availability to plants due to the high adsorption/fixation power of this nutrient (Novais and Smyth, 1999).

In Minas Gerais, the subsoil in many places present high $\mathrm{Al}$ saturation and low Ca saturation in the exchange complex and it limits the soil exploration by the roots in the search for moisture and nutrients (Vale et al., 1996). In this sense, some practices are needed to correct these soil properties to allow the development of the species that are being cultivated. The application of correctives intends to decrease the toxic concentrations of $\mathrm{Al}$ and $\mathrm{Mn}$, to provide favorable conditions for the development of microorganisms that decompose the organic matter, nitrificators and $\mathrm{N}$ fixers, to increase the availability of $\mathrm{P}$ and Mo and the supply of $\mathrm{Ca}$ and Mg (Malavolta, 1980).

Based on the above considerations, the objective of the present study was to evaluate the growth and quality of Plathymenia foliolosa Benth seedlings under the influence of phosphate fertilization and base saturation of substrate.

\section{MATERIALS AND METHODS}

The experiment was conducted in the nursery belonging to the Department of Forest Engineering of the Federal University of Viçosa, Viçosa Campus, between October 2012 and March 2013. Viçosa (20 $45^{\prime} \mathrm{S} ; 46^{\circ} 51^{\prime} \mathrm{W}$ ) has annual average temperature of $19.4^{\circ} \mathrm{C}$, annual average rainfall of $1221 \mathrm{~mm}$ (DNMET, 1992), and altitude of $698 \mathrm{~m}$. According to Köppen climate classification, such region is a "Cwb" type zone, mesothermal climate, with hot rainy summers and cool dry winters.

The substrate used was a dystrophic clayey RedYellow Latosol taken from an area belonging to the Viçosa Federal University, in Viçosa Campus, at 20$50 \mathrm{~cm}$ depth. The soil was sieved with $4 \mathrm{~mm}$ mesh. Subsequently, the pots were filled with it. A soil sample was collected for physical (clay $=570 \mathrm{~g} \mathrm{~kg}^{-1}$, silt $=$ 
$110 \mathrm{~g} \mathrm{~kg}^{-1}$, coarse sand $=190 \mathrm{~g} \mathrm{~kg}^{-1}$ and fine sand $=130 \mathrm{~g} \mathrm{~kg}^{-1}$ ) and chemical characterization (Table 1).

The treatments consisted of six phosphorus doses $\left(0,120,240,360,480\right.$ and $\left.600 \mathrm{mg} \mathrm{dm}^{-3}\right)$ and five levels of base saturation of substrate $(3.5,25,40,55$ and $70 \%)$, which were combined in a factorial arrangement. The experimental design used was the randomized blocks with four replications. Each experimental plot consisted of a $1.8 \mathrm{dm}^{3}$ capacity pot.

The soil received five liming levels according to the method of base saturation:

$$
L R=[(B S 2-B S 1) \times C E C] \div 100
$$

Where:

$\mathrm{LR}=$ lime requirement $\left(\mathrm{tha}^{-1}\right)$;

$\mathrm{BS} 2=$ desired base saturation $(25,40,55$ and $70 \%)$;

$\mathrm{BS} 1=$ current base saturation, according to chemical analysis (equal at $3.5 \%$ );

\section{$\mathrm{CEC}=$ Cation Exchange Capacity at $\mathrm{pH} 7$.}

The soil acidity corrective consisted of a $\mathrm{CaCO}_{3}$ and $\mathrm{MgCO}_{3}$ mixture, in 4:1 ratio. After applying it, the soil was incubated for 30 days and its moisture content was kept at field capacity, including the soil that did not receive the liming.

The P source used was the Sodium Phosphate Monobasic Monohydrate $\left(\mathrm{NaH}_{2} \mathrm{PO}_{4} \cdot \mathrm{H}_{2} \mathrm{O}\right)$ that was applied by solution before the seedlings pricking out. After 15 days that the seedlings were pricked out, the basic fertilization was made by a solution with $100 \mathrm{mg}$ $\mathrm{dm}^{-3}$ of $\mathrm{N}, 100 \mathrm{mg} \mathrm{dm}^{-3}$ of $\mathrm{K}$ and $40 \mathrm{mg} \mathrm{dm}^{-3}$ of S, using $\mathrm{NH}_{4} \mathrm{NO}_{3}, \mathrm{KCl}$ and $\mathrm{K}_{2} \mathrm{SO}_{4}$, respectively, as suggested by Passos (1994). The supplementary fertilization was made with $50 \mathrm{mg} \mathrm{dm}^{-3}$ of $\mathrm{N}$ and $25 \mathrm{mg} \mathrm{dm}^{-3}$ of $\mathrm{K}$, in two applications interleaved in a 30-day interval. With the first fertilization, it was made an application of a micronutrients solution with the following dosage:
$0.81 \mathrm{mg} \mathrm{dm}^{-3}$ of $\mathrm{B}\left(\mathrm{H}_{3} \mathrm{BO}_{3}\right), 1.33 \mathrm{mg} \mathrm{dm}^{-3}$ of Cu $(\mathrm{CuSO}$ $4.5 \mathrm{H} 2 \mathrm{O}), 3.66 \mathrm{mg} \mathrm{dm}^{-3}$ of $\mathrm{Mn}\left(\mathrm{MnCl}_{2} . \mathrm{H}_{2} \mathrm{O}\right), 4.00 \mathrm{mg}$ $\mathrm{dm}^{-3}$ of $\mathrm{Zn}\left(\mathrm{ZnSO}_{4} \cdot 7 \mathrm{H}_{2} \mathrm{O}\right)$, and $0.15 \mathrm{mg} \mathrm{dm}^{-3}$ of $\mathrm{Mo}\left(\left(\mathrm{NH}_{4}\right)_{6}\right.$ $\mathrm{Mo}_{7} \mathrm{O}_{24} \cdot 4 \mathrm{H}_{2} \mathrm{O}$ ), according to recommendation of Alvarez V. et al. (2006),

The Plathymenia foliolosa seeds were placed in sulfuric acid for 10 minutes to break the dormancy. The seeds were sown in sand and 32 days after, when they had two pairs of leaves, it was made the pricking out and then they were transplanted. Each pot received two seedlings and the pots were placed in a nursery shade house (shade cloth, 50\% black), where they remained for 15 days. Then, the seedlings were placed into greenhouse and it was made the thinning of them, leaving only one seedling per pot.

During the experiment, the soil moisture was monitored daily, and the irrigation was made when needed.

At1 18 days after the seedlings pricking out, the height of aerial part $(\mathrm{H})$ and the neck diameter (D) were obtained using a graduated ruler in centimeter and digital caliper with precision of $0.01 \mathrm{~mm}$, respectively. The plants were separated into roots and shoots, washed and dried in a forced-air oven at $70^{\circ} \mathrm{C}$ until they reached constant weight. The determination of root dry matter (RDM) and shoot dry matter (SDM) weights was performed on an analytical scale with $0.01 \mathrm{~g}$ accuracy, and the total dry matter weight (TDM) was obtained by summing RDM and SDM.

With the data of height of aerial part $(\mathrm{H})$, neck diameter (D), root dry matter weight (RDM), shoot dry matter weight (SDM), total dry matter weight (TDM), the relations of seedling quality were calculated: SDM/ RDM and Dickson Quality Index (DQI), according to the formula:

$$
D Q I=T D M \div[(H \div D)+(S D M \div R D M)]
$$

Table 1 - Chemical analysis of the sample of soil used in the seedlings production of Plathymenia foliolosa Benth.

Tabela 1 - Análise química da amostra do solo utilizado para a produção de mudas de vinhático-da-mata (Plathymenia

\begin{tabular}{|c|c|c|c|c|c|c|c|c|c|c|c|c|}
\hline \multirow{2}{*}{$\begin{array}{c}\mathrm{pH} \\
\mathrm{H}_{2} \mathrm{O}\end{array}$} & $\mathrm{P}$ & $\mathrm{K}$ & $\mathrm{Al}^{3+}$ & $\mathrm{Ca}^{2+}$ & $\mathrm{Mg}^{2+}$ & $\mathrm{H}+\mathrm{Al}$ & $\mathrm{SB}$ & CEC(t) & CEC(T) & $\mathrm{BS}$ & $\mathrm{m}$ & \multirow{2}{*}{$\begin{array}{c}\mathrm{OM} \\
\text { dag kg } \mathrm{kg}^{-1} \\
\end{array}$} \\
\hline & \multicolumn{2}{|c|}{$-\mathrm{mg} \mathrm{dm}^{-3}-$} & \multicolumn{7}{|c|}{$\mathrm{cmol}_{\mathrm{c}} \mathrm{dm}^{-3}$} & \multicolumn{2}{|c|}{$(\%)$} & \\
\hline 4.79 & 0.70 & 6.00 & 0.92 & 0.11 & 0.01 & 3.93 & 0.14 & 1.06 & 4.04 & 3.5 & 86.80 & 1.66 \\
\hline
\end{tabular}
foliolosa Benth.). 
The results were evaluated by variance and regression analysis $(\mathrm{p}<0.05)$. The regression equations were adjusted for the applied $\mathrm{P}$ doses and liming levels. The models were chosen by the biological realism, significance of regression parameters and the coefficient of determination $\left(\mathrm{R}^{2}\right)$. It was also calculated the Pearson correlation coefficient to evaluate the correlation between H, D, RDM, SDM, TDM and DQI.

\section{RESULTS}

Phosphate fertilization had a significant effect $(p<0.05)$ in all evaluated characteristics, SDM/RDM and DQI (Table 2). The effect of base saturation of substrate was also significant $(\mathrm{p}<0.05)$, except for SDM/RDM. Significant interaction $(\mathrm{p}<0.05)$ was not observed between base saturation and phosphate fertilization.

The increase of base saturation influenced negatively the seedlings growth and quality. The evaluated characteristics and the DQI presented a linear response (Figure 1). The highest values for all morphological characteristics $(\mathrm{H}=31.54 \mathrm{~cm}, \mathrm{D}=6.68$ $\mathrm{mm}, \mathrm{SDM}=5.48 \mathrm{~g}, \mathrm{RDM}=1.83 \mathrm{~g}, \mathrm{TDM}=7.30 \mathrm{~g})$ and DQI (0.83), were observed at the original base saturation of the soil $(3.5 \%)$.

Phosphate fertilization provided advances in seedlings growth and quality. All studied variables had quadratic response for phosphorus doses (Figure 2). The maximum values for $\mathrm{H}(31.50 \mathrm{~cm}), \mathrm{D}(6.42 \mathrm{~mm})$, SDM (5.10 g), RDM (1.60 g), TDM (6.73 g) and DQI (0.77) were obtained between 275 and $315 \mathrm{mg} \mathrm{dm}^{-3}$ of P.

The result of SDM/RDM ratio equal to 2.0, which is indicated for good quality seedlings (Gomes and
Paiva, 2012) was not observed in this study. The maximum point for that ratio (3.47) was obtained with 370.33 $\mathrm{mg} \mathrm{dm}^{-3}$ of $\mathrm{P}$, and the treatment without $\mathrm{P}$ addition presented the value closer to that indicated. The correlations between the dependent variables were higher than 0.70 . The lowest correlations were obtained for H-DQI (0.71) and H-RDM (0.78) (Table 3).

\section{DISCUSSION}

Tree species respond differently to the application of soil acidity correctives, depending on their tolerance to acid soils. Valeri et al. (1985) observed negative response to the application of calcium carbonate on the height and diameter growth of Eucalyptus grandis plants. The negative response to liming on Plathymenia foliolosa seedlings can be explained by the plant adaptation to acid soils and the levels of available $\mathrm{Ca}$ and $\mathrm{Mg}$ in the soil are sufficient for initial demand of plants. Bernardino et al. (2007) evaluated the influence of base saturation, using Alic Latosol ( $\mathrm{BS}=3.6 \%)$ as a substrate, on the growth and quality of Dalbergia nigra seedlings. They concluded that it was not necessary to make the acidity correction of substrate for the production of quality seedlings.

A different response was found by Tucci et al. (2010) in which liming favored the production of quality seedlings of Ochroma lagopus. These authors did not observe significant effects of liming on phosphorus absorption and concluded that liming in this case did not contribute to the accumulation of that nutrient.

The maximum height of aerial part and neck diameter obtained in this study are in or near the range set by Gonçalves et al. (2005) for good quality seedlings: 20$35 \mathrm{~cm}$ of height and 5-10 mm of neck diameter. The

Table 2 - Summary of the variance analysis of the studied morphologic characteristics and relations in the production of Plathymenia foliolos a seedlings in response to base saturation of substrate (BS) and phosphate fertilization (P). The morphologic characteristics and relations were evaluated at 118 days after transplanting.

Tabela 2 - Resumo da análise de variância das características morfológicas e suas relações para mudas de Plathymenia foliolosa aos 118 dias após a repicagem, em resposta às doses de fósforo e saturação por bases do substrato.

\begin{tabular}{|c|c|c|c|c|c|c|c|c|}
\hline \multirow[t]{2}{*}{ Source } & \multirow[t]{2}{*}{ df } & \multicolumn{7}{|c|}{ p-value } \\
\hline & & $\mathrm{H}(\mathrm{cm})$ & $\mathrm{D}(\mathrm{mm})$ & SDM (g) & RDM (g) & TDM (g) & $\mathrm{SDM} / \mathrm{RDM}$ & DQI \\
\hline Block & 3 & 0.0121 & 0.0950 & 0.0464 & 0.1897 & 0.0627 & 0.6415 & 0.2835 \\
\hline BS & 4 & 0.0024 & 0.0000 & 0.0000 & 0.0000 & 0.0000 & 0.9898 & 0.0000 \\
\hline $\mathrm{P}$ & 5 & 0.0011 & 0.0000 & 0.0000 & 0.0000 & 0.0000 & 0.0192 & 0.0000 \\
\hline Px BS & 20 & 0.2040 & 0.3897 & 0.1195 & 0.3298 & 0.1435 & 0.8067 & 0.3438 \\
\hline CV\% & & 34.56 & 29.86 & 58.18 & 65.35 & 58.70 & 33.66 & 65.40 \\
\hline
\end{tabular}

$\mathrm{H}$ - height of aerial part; D - neck diameter; SDM - shoot dry matter; RDM - root dry matter; TDM - total dry matter; SDM/RDM -shoot dry matter/root dry matter relation; DQI - Dickson Quality Index. 


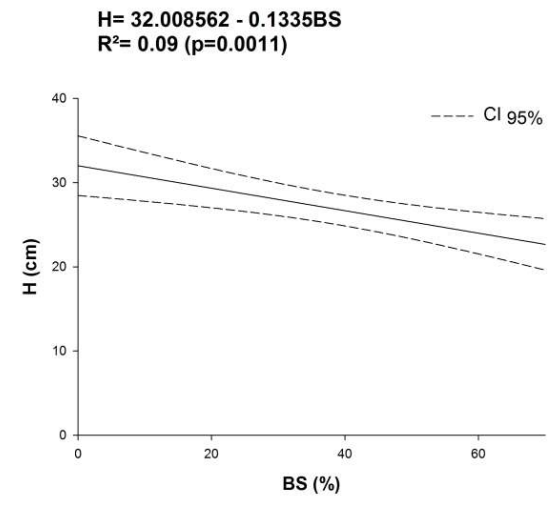

(a)

SDM $=5.6380-0.04629 B S$ $R^{2}=0.13(p=0.0000)$

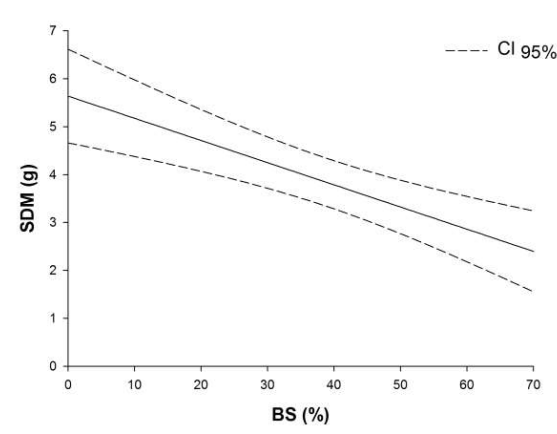

(c)

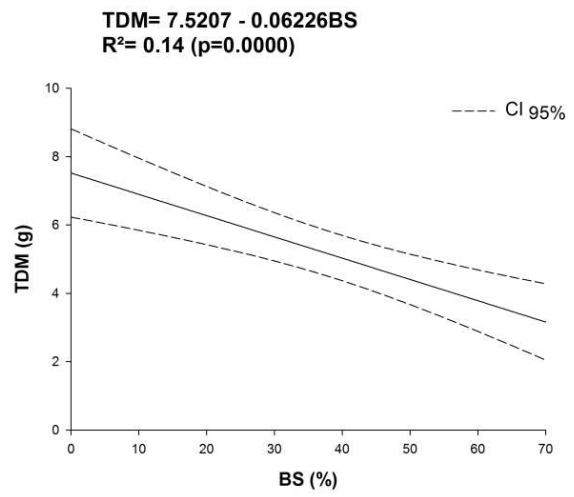

(e)

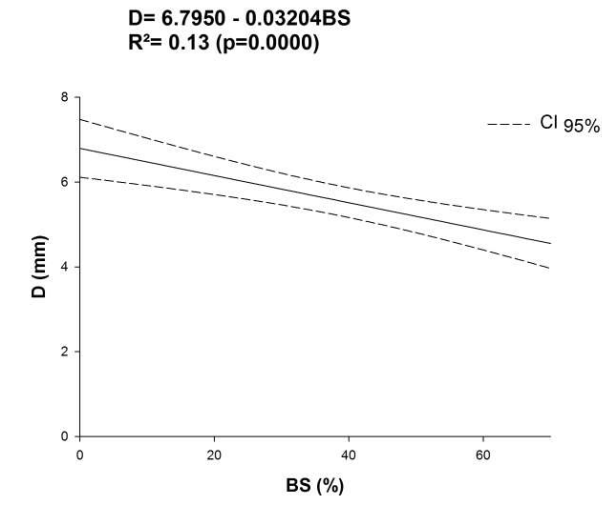

(b)

$R D M=1.8827-0.01597 B S$ $R^{2}=0.14(p=0.0000)$

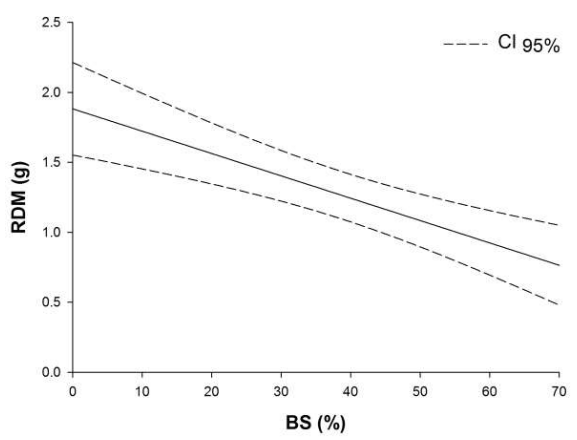

(d)

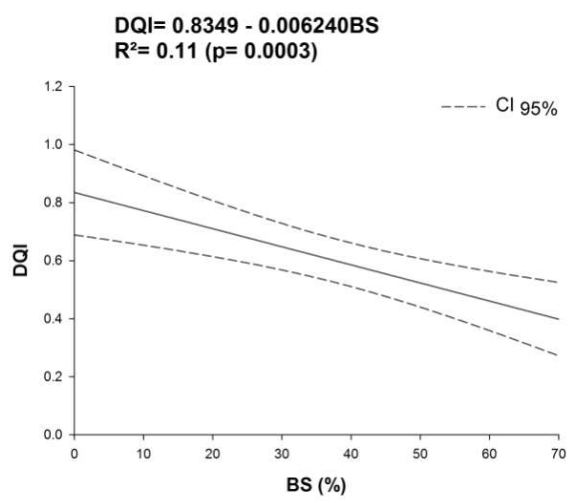

(f)

Figure 1 - Height of aerial part (H) (a), neck diameter (D) (b), shoot dry matter (SDM) (c), root dry matter (RDM) (d), total dry matter (TDM) (e), Dickson Quality Index (DQI) (f), with confidence intervals (CI), for Plathymenia foliolosa seedlings in response to base saturation of substrate (BS). The morphologic characteristics were evaluated at 118 days after transplanting.

Figura 1 - Altura da parte aérea (H) (a), diâmetro do coleto (D) (b), massa de matéria seca da parte aérea (SDM) (c), massa de matéria seca da raiz (RDM) (d), massa de matéria seca total (TDM) (e), e indice de qualidade Dickson (DQI) (f) de mudas de Plathymenia foliolosa, aos 118 dias após a repicagem, em resposta à saturação por bases do substrato, com os respectivos intervalos de confiança (CI). 


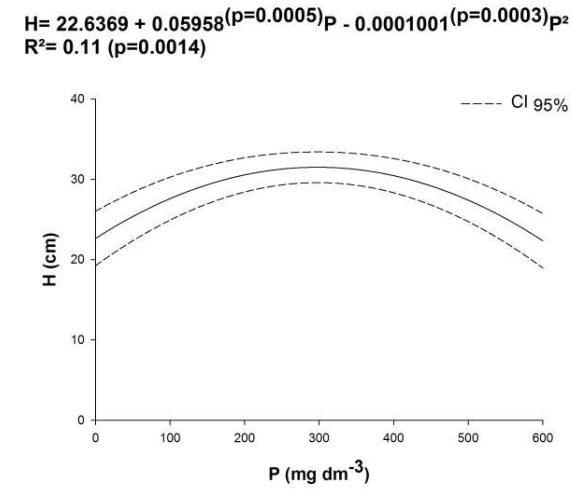

(a)

$S D M=2.4618+0.01808^{(p=0.0000)} P-0.00003061^{(p=0.0000)} P^{2}$ $R^{2}=0.14(p=0.0001)$

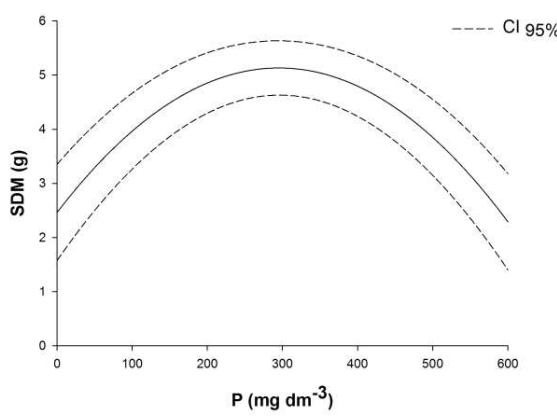

(c)

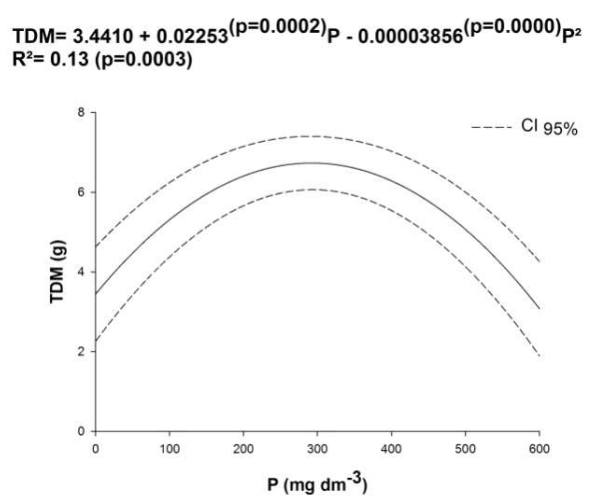

(e)
$D=4.4122+0.01279^{(p=0.0000)} P-0.00002042^{(p=0.0000)} p^{2}$ $R^{2}=0.13(p=0.0002)$

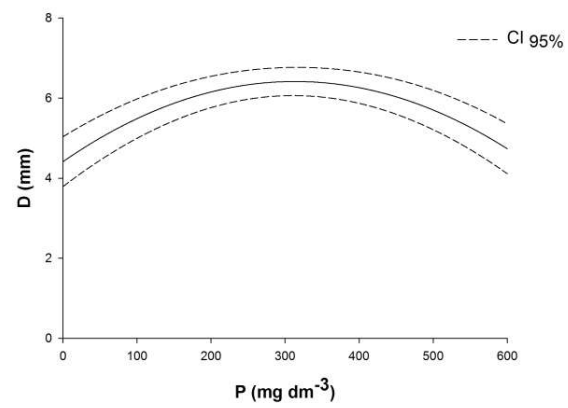

(b)

$R D M=0.9792+0.004447^{(p=0.0046)} P-0.000007944^{(p=0.0016)} P^{2}$ $R^{2}=0.09(p=0.0053)$

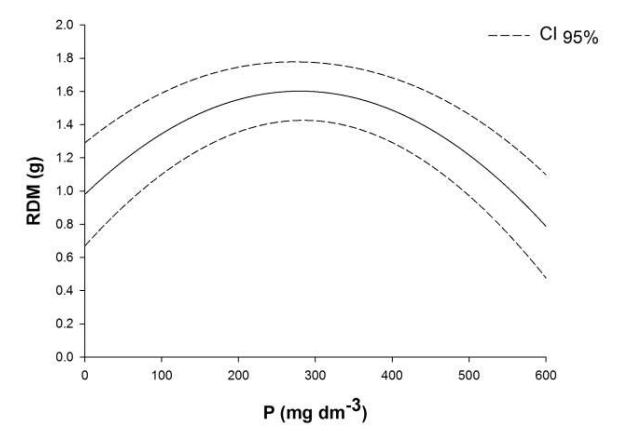

(d)

$D Q I=0.3969+0.002545^{(0.0001)} P-0.000004334^{(p=0.0000)} P^{2}$ $R^{2}=0.13(p=0.0004)$

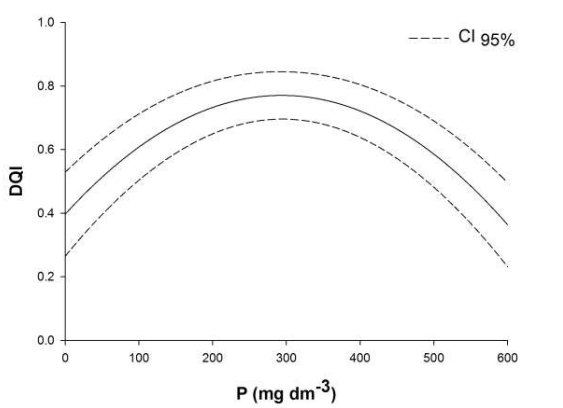

(f)

Figure 2 - Height of aerial part (H) (a), neck diameter (D) (b), shoot dry matter (SDM) (c), root dry matter (RDM) (d), total dry matter (TDM) (e), Dickson Quality Index (DQI) (f), and relation shoot dry matter/ root dry matter (SDM/RDM) (g), with confidence intervals(CI), for Plathymenia foliolosa seedlings in response to phosphate fertilization. The morphologic characteristics were evaluated at 118 days after transplanting.

Figura 2 - Altura da parte aérea (H) (a), diâmetro do coleto (D) (b), massa de matéria seca da parte aérea (SDM) (c), massa de matéria seca da raiz (RDM) (d), massa de matéria seca total (TDM) (e), índice de qualidade Dickson (DQI) (f), e relação entre massa de matéria seca da parte aérea e massa de matéria seca da raiz (SDM/RDM) (g) de mudas de Plathymenia foliolosa, aos 118 dias após a repicagem, em resposta à adubação fosfatada, com os respectivos intervalos de confiança (CI).

Revista Árvore. 2017;41(1):e410111 
Table 3 - Pearson correlation coefficient between variables: height of aerial part (H), neck diameter (D), shoot dry matter (SDM), root dry matter (RDM), total dry matter (TDM) and Dickson Quality Index (DQI).

Tabela 3 - Coeficiente de correlação de Pearson entre as variáveis estudadas: altura da parte aérea (H), diâmetro do coleto (D), massa de matéria seca da parte aérea (SDM), massa de matéria seca da raiz (RDM), massa de matéria seca total (TDM), e indice de qualidade de Dickson (DQI).

\begin{tabular}{lccccc}
\hline Variables & $\mathrm{D}(\mathrm{mm})$ & $\mathrm{SDM}(\mathrm{g})$ & $\mathrm{RDM}(\mathrm{g})$ & $\mathrm{TDM}(\mathrm{g})$ & $\mathrm{DQI}$ \\
\hline $\mathrm{H}(\mathrm{cm})$ & $0.88^{* *}$ & $0.86^{* *}$ & $0.78^{* *}$ & $0.85^{* *}$ & $0.71^{* *}$ \\
$\mathrm{D}(\mathrm{mm})$ & & $0.94^{* *}$ & $0.88^{* *}$ & $0.94^{* *}$ & $0.89^{* *}$ \\
SDM $(\mathrm{g})$ & & $0.94 * *$ & $0.99^{* *}$ & $0.94^{* *}$ \\
RDM $(\mathrm{g})$ & & & $0.96^{* *}$ & $0.98^{* *}$ \\
TDM $(\mathrm{g})$ & & & & $0.96^{* *}$ \\
\hline
\end{tabular}

** Significant at 0.01 level of probability

height of aerial part and neck diameter are the most assessed characteristics in nurseries to classify the quality of seedlings because they are easily checked, do not need a destructive method and correlate with the growth and survival of seedlings in the field after planting (Carneiro, 1995). In relation to dry matter of plants, this is very important because it correlates with the vigor and photosynthetic capacity, being desirable that this variable presents the maximum of itself (Cruz et al., 2011).

Although the height of aerial part, neck diameter and dry matter weight are good indicators of seedling quality, these should not be used in isolation to avoid mistakes in seedling selection. Fonseca et al. (2002) observed that Trema micrantha seedlings that are grown under larger shade periods, presented the worst quality with the reduction of the neck diameter, root dry matter weight and Dickson Quality Index although they have reached higher height of aerial part and leaf area. The Dickson Quality Index is a good indicator of seedlings quality, cause its calculation considers the robustness and the balance of mass distribution in the seedling, in other words, important characteristics used for quality evaluation (Fonseca et al., 2002). Higher is the index, better is the seedling quality.

Phosphate fertilization influenced positively the quality of seedlings. Phosphorus has a strong relation with the indexes that express the seedlings quality, providing a higher survival rate of seedlings in the field (Caione et al., 2012), and consequently reducing post-planting losses. Several Brazilian forest species also respond to phosphate fertilization positively, such as paricá (Schizolobium amazonicum (Huber ex Ducke)) (Caione et al., 2012); sansão-do-campo (Mimosa caesalpiniifolia Benth.) (Gonçalves et al., 2010); angicoamarelo (Peltophorum dubium (Spreng) Taub.)
(Schumacher et al., 2003); pata-de-vaca (Bauhinia forficata Link) (Brondani et al., 2008); fedegoso (Senna macranthera (DC. Ex Collad.) H.S.Irwin \& Barneby)) (Cruz et al., 2011); açoita-cavalo (Luehea divaricata Mart.) (Ceconi et al., 2006); angico-vermelho (Anadenanthera macrocarpa (Benth.) Brenan) (Gonçalves et al., 2008), corroborating with the results of this study.

The result of SDM/RDM close to 2.0, value indicated for good quality seedlings, was obtained in the treatment without phosphorus application, unlike the maximum values obtained for all the characteristics and DQI. That happens because under conditions of low availability of phosphorus the plant allocates greater growth potential to the root system (Soares et al., 2007). Fernandes et al. (2000) observed a greater production of SDM in relation to RDM in seedlings of aroeirinha (Schinus terenbinthifolius Raddi), paineira (Chorisia speciosa A.St.-Hil.) andjambolão (Syzygium jambolanum (Lam.) DC.) when the phosphorus supply was increased.

A positive correlation between the dependent variables was observed in this study. Therefore, it is possible to infer about the seedlings quality and recommend the phosphate fertilization and substrate acidity correction through the data of height of aerial part and neck diameter. This is important because they are not obtained through destructive methods. However, the dry matter data express the photosynthetic capacity of the plant better and can reduce the erroneous classification of seedlings quality, for example, in the case of seedlings with higher heights due to etiolation. Thus, shoot dry matter mass is a potential variable in order to infer about the seedlings quality, since it has a high correlation with the other variables and is easier to obtain than root dry matter.

Revista Árvore. 2017;41(1):e410111 


\section{CONCLUSION}

In the studied conditions, phosphate fertilization influences positively the Plathymenia foliolosa seedlings growth and quality. The opposite is observed for the increase of the base saturation of substrate, which influences negatively all studied characteristics and relations.

The phosphorus dose that provides the best seedlings quality and growth of Plathymenia foliolosa is $300 \mathrm{mg} \mathrm{dm}^{-3}$. Besides, the liming is not necessary.

\section{ACKNOWLEDGMENT}

We thank CAPES (Coordenação de Aperfeiçoamento de Pessoal de Nível Superior) for the master's degree fellowship and CNPq (Conselho Nacional de Desenvolvimento Científico e Tecnológico) for the research productivity fellowship.

\section{REFERENCES}

Alvarez V VH, Dias LE, Leite PB, Souza RB, Ribeiro Junior ES. Poda de raízes e adubação para crescimento do cafeeiro cultivado em colunas de solo. Revista Brasileira de Ciência do Solo. 2006;30(1):111-9.

Bernardino DCS, Paiva HN, Neves JCL, Gomes JM, Marques VB. Influência da saturação por bases e da relação $\mathrm{Ca}: \mathrm{Mg}$ do substrato sobre o crescimento inicial de jacarandá-da-bahia (Dalbergia nigra (Vell.) Fr. All. ex Benth.). Revista Árvore. 2007;31(4):567-73.

Brondani GE, Silva AJC, Araujo MA, Grossi F, Wendling I, Carpanezzi AA. Phosphorus nutrition in the growth of Bauhinia forficata L. seedlings. Acta Scientiarum Agronomy. 2008;30(5):665-71.

Caione G, Lange A, Schoninger EL. Crescimento de mudas de Schizolobium amazonicum (Huber ex Ducke) em substrato fertilizado com nitrogênio, fósforo e potássio. Scientia Forestalis. 2012;40(94):213-21.

Carneiro JGA. Produção e controle de qualidade de mudas florestais. Curitiba: UFPR/FUPEF/UENF; 1995. $451 \mathrm{p}$.

Ceconi DE, Poletto I, Brun EJ, Lovato T. Crescimento de mudas de açoita-cavalo (Luehea divaricata Mart.) sob influência da adubação fosfatada. Cerne. 2006;12(3):292-9.

Costa GS, Franco AA, Damasceno RN, Faria SM. Aporte de nutrientes pela serapilheira em uma área degradada e revegetada com leguminosas arbóreas. Revista Brasileira de Ciência do Solo. 2004;28(5):919-27.

Cruz CAF, Paiva HN, Gomes KCO, Guerrero CRA. Efeito de diferentes níveis de saturação por bases no desenvolvimento e qualidade de mudas de ipê-roxo (Tabebuia impetiginosa (Mart.) Standley). Scientia Forestalis. 2004(66):100-7.

Cruz CAF, Paiva HN, Cunha ACMCM, Neves JCL. Crescimento e qualidade de mudas de Fedegoso cultivadas em Latossolo VermelhoAmarelo em resposta a macronutrientes. Scientia Forestalis. 2011;39(89):21-33.

Dechen AR, Nachtigall GR. Elementos requeridos à nutrição de plantas. In: Novais RF. et al. editores. Fertilidade do solo. Viçosa, MG: Sociedade Brasileira de Ciências do Solo; 2007. p.91-132.

Departamento Nacional de Meteorologia DNMET. Normais climatológicas (1961-1990). Brasília: SPI/EMBRAPA; 1992.

Fernandes LA, Furtini Neto AE, Fonseca FC, Vale FR. Crescimento inicial, níveis críticos de fósforo e frações fosfatadas em espécies florestais. Pesquisa Agropecuária Brasileira. 2000;35(6):1191-8.

Fonseca EP, Valéri SV, Miglioranza E, Fonseca NAN, Couto L. Padrão de qualidade de mudas de Trema micrantha (L.) Blume, produzidas sob diferentes períodos de sombreamento. Revista Árvore. 2002;26(4):515-23.

Gomes JM, Paiva HN. Viveiros florestais: propagação sexuada. Viçosa, MG: Universidade Federal de Viçosa; 2012. 116p.

Gonçalves JLM, Santarelli EG, Moraes Neto SP, Manara MP. Produção de mudas de espécies nativas: substrato, nutrição, sombreamento e fertilização. In: Gonçalves JLM, Benedeti V, editores. Nutrição e fertilização florestal. Piracicaba: IPEF; 2005. p.309-50. 
Gonçalves EO, Paiva HN, Neves JCL, Gomes JM. Crescimento de mudas de angico-vermelho (Anadenanthera macrocarpa (Benth.) Brenan) sob diferentes doses de macronutrientes. Revista Árvore. 2008;32(6):1029-40.

Gonçalves EO, Paiva HN, Neves JCL, Gomes JM. Crescimento de mudas de sansão-do-campo (Mimosa caesalpiniaefolia Benth.) sob diferentes doses de macronutrientes. Scientia Forestalis. 2010;38(88):599-609.

Lorenzi H. Árvores brasileiras: manual de identificação e cultivo de plantas arbóreas nativas do Brasil. $4^{\mathrm{a}}$.ed. Nova Odessa: Instituto Plantarum; 2002. 368p.

Malavolta E. Elementos de nutrição mineral de plantas. São Paulo: Ceres; 1980. 251p.

Novais RF, Smyth TJ. Fósforo em solo e planta em condições tropicais. Viçosa, MG: Sociedade Brasileira de Ciência do Solo; 1999. 399p.

Passos MAA. Efeito da calagem e de fósforo no crescimento inicial da algaroba (Prosopis juliflora (SW) DC) [tese]. Viçosa, MG: Universidade Federal de Viçosa; 1994. 57p.

Schumacher MV, Cecon DE, Santana CA. Influência de diferentes doses de fósforo no crescimento de plantas de Peltophorum dubium (Sprengel) Taubert. Boletim de Pesquisa Florestal. 2003(47):99-114.

Silva AF, Oliveira RV, Santos NRS, Paula A. Composição florística e grupos ecológicos das espécies de um trecho de floresta semidecídua submontana da fazenda São Geraldo, Viçosa-MG Revista Árvore. 2003;27(3):311-9.

Soares I, Lima SC, Crisóstomo LA.Crescimento e composição mineral de mudas de gravioleira em resposta a doses de fósforo. Revista Ciência Agronômica. 2007;38(4):343-9.

Tucci CAF, Lima HN, Gama AS, Costa HS, Souza PA. Efeitos de doses crescentes de calcário em solo Latossolo Amarelo na produção de mudas de pau-de-balsa (Ochroma lagopus sw., Bombacaceae). Acta Amazonica. 2010;40(3):543-8.

Vale FR, Furtini Neto AE, Renó NB, Fernandes LA, Resende AV. Crescimento radicular de espécies florestais em solo ácido. Pesquisa Agropecuária Brasileira. 1996;31(9):609-16.

Valeri SV, Aguiar IB, Corradini L, Souza ECA, Banzatto DA.Efeito do fósforo e cálcio no desenvolvimento e na composição química foliar de Eucalyptus grandis Hill ex Maiden em casa de vegetação. IPEF. 1985(29):47-54. 